\title{
HUBUNGAN ANTARA KEPRIBADIAN DENGAN KECERDASAN EMOSI SISWA KELAS VII MTS MANBA'UL BAYAN LINGKUNG KABUPATEN LOMBOK TENGAH
}

\author{
Ismariyati Kiwang ${ }^{1}$, Ani Endriani ${ }^{2}$ \\ Program Studi Bimbingan dan Konseling, FIPP UNDIKMA \\ Email: aniendriani@ikipmataram.ac.id
}

\begin{abstract}
Abstrak: Kepribadian adalah ketrampilan atau kecakapan sosial (social skill), dan kesan yang paling menonjol, yang ditunjukan seseorang terhadap orang lain (seperti seseorang yang dikesankan sebagai orang yang agresif atau pendiam). Sedangkan kecerdasan emosi adalah kemampuan untuk mengenali diri sendiri, mengelola emosi dengan produktif, dan membina hubungan dengan baik, mengenali perasaan sewaktu perasaan yang dirasakan terjadi merupakan dasar kecerdasan emosional. Adapun rumusan masalah dalam penelitian ini adalah apakah ada hubungan antara kepribadian dengan kecerdasan emosi siswa kelas VII MTs.Manba'ul Bayan Lingkung Kabupaten Lombok Tengah Tahun Pelajaran 2015/2016. Adapun tujuan dalam penelitian ini adalah sebagai berikut: untuk mengetahui apakah ada hubungan antara kepribadian dengan kecerdasan emosi siswa kelas VII MTs. Manba'ul Bayan Lingkung Kabupaten Lombok Tengah Tahun Pelajaran 2015/2016.Populasi dalam penelitian adalah seluruh siswa kelas VII di MTs. Manba'ul Bayan Lingkung Kabupaten Lombok Tengah Tahun Pelajaran 2015/2016 yang terdiri dari 7 laki-laki dan 12 perempuan. Metode pengumpulan data adalah metode angket sebagai metode pokok dan metode wawancara, observasi serta dokumentasi sebagai metode pelengkap. Tekhnik Analisis data yang digunakan dalam penelitian ini adalah menggunakan rumus product moment. Hasil penelitian menunjukkan bahwa ada hubungan antara kepribadian dengan kecerdasan emosi siswa pada kelas VII di MTs. Manba'ul Bayan Lingkung Kabupaten Lombok Tengah Tahun Pelejaran 2015/2016, diperoleh berdasarkan analasisi data pada siswa kelas VIII SMPN Negeri 6 Praya Timur Lombok Tengah Tahun Pelajaran 2015/2016, di peroleh berdasarkan analisis data menggunakan rumus product moment diperoleh hasil yakni $\mathrm{r}$ hitung sebesar 0,579, sedangkan nilai $\mathrm{r}$ tabel pada taraf signifikansi 5\% dengan $\mathrm{N}=19$ tersebut diperoleh sebesar 0,456. Dengan demikian, nilai $r$ hitung menunjukkan lebih besar dari pada nilai $r$ tabel sebesar 0,579 atau $(0,58>0,456$. Kesimpulan analisis dalam penelitian ini adalah sebagai berikut: Ada hubungan antara kepribadian dengan kecerdasan emosi siswa pada kelas VII di MTs. Manba'ul bayan Lingkung Kabupaten Lombok Tengah Tahun Pelejaran 2015/2016 Signifikan.
\end{abstract}

\section{Kata Kunci : Kepribadian, Kecerdasan Emosi}

\section{LATAR BELAKANG}

Dalam bahasa populer, istilah

"kepribadian" juga berarti ciri-ciri watak seseorang individu yang konsisten, yang memberikan kepadanya suatu identitas sebagai individu yang khusus. Jika dalam bahasa sehari-hari kita anggap bahwa seseorang mempunyai kepribadian, kita maksudkan ialah orang tersebut memiliki beberapa ciri watak yang diperlihatkan secara lahir, konsisten dan konsekuen dalam tingkah lakunya, sehingga tampak bahwa individu tersebut memiliki identitas yang khusus yang berbeda dari individu lainnya. (Sobur, 2003: 301).

Definisi umum yang banyak menyerupai arti konsep dalam bahasa sehari-hari tersebut itu hendak dipertajam, akan timbul banyak kesukaran. Hal itu sudah banyak dilakukan oleh para ahli psikolog yang berasal dari berbagai aliran khusus dalam ilmu psikolog yang merupakan tugas mereka, tetapi tidak ada satu definisi yang tajam dan seragam. Agaknya, konsep kepribadian merupakan 
konsep yang begitu luas, sehingga menjadi suatu kontruksi yang tidak mungkin dirumuskan dalam suatu definisi yang tajam, namun bisa mencakup keseluruhannya.

Kepribadian adalah merupakan ketrampilan atau kecakapan sosial (social skill), atau kesan yang paling menonjol, yang ditunjukan seseorang terhadap orang lain (seperti seseorang yang dikesankan sebagai orang yang agresif atau pendiam). Individu yang memiliki kepribadian yang seperti, kepercayaan dalam diri sendiri dan orang lain; yaitu kepercayaan pada dunia luar. Menurut Cervone dan Pervin (2011: 10) menyebutkan bahwa kepribadian merupakan kualitas psikologis yang memberikan kontribusi terhadap ketahanan (enduring) individu dan pola khusus dari perasaan, pola pikir, dan perilaku. Sedangkan menurut Syarif (dalam Rahayu, 2009 : 74).

Individu yang tidak memiliki kepribadian yang kurang baik seperti, sifat ingin membalas dendam; bereaksi terlalu radikal terhadap orang lain maupun dirinya sendiri; tidak mengakui dan tidak menerima masa lalunya, lalu mau mengubah diri secara sangat radikal (identitas negatif).

Kecerdasan emosi adalah mencakup kemampuan untuk membedakan dan menanggapi dengan tepat suasana hati, temperamen, motivasi dan hasrat antar pribadi ini lebih menekankan pada aspek kognisi atau pemahaman. Sementara faktor emosi atau perasaan kurang diperhatikan. Padahal menurut Goleman, faktor emosi ini sangat penting dan memberikan suatu warna yang kaya dalam kecerdasan antarpribadi. Sedangkan menurut Juntika (2009:240): Kecerdasan emosi adalah kemampuan memahami diri, mengelola emosi, memanfaatkan emosi secara produktif, empati dan membina hubungan.

Dalam mengembangkan anak untuk menjadi sumber daya manusia yang berkualitas diperlukan persiapan dan perlakuan terhadap anak secara tepat sesuai dengan kondisi anak. Sebagai manusia, setiap anak mempunyai kecerdasan emosi yang berbeda satu dengan yang lain. Kecerdasan emosi kemampuan menggunakan emosi secara efek tif untuk mencapai tujuan, membangun hubungan produktif dan meraih keberhasilan. Adapun Fatimah (2008:115) mengatakan bahwa: Kecerdasan emosi adalah menuntut diri untuk belajar mengakui dan menghargai perasaan diri sendiri dan orang lain".

Kecerdasan emosi adalah mencakup kemampuan untuk membedakan dan menanggapi dengan tepat suasana hati, temperamen, kemampuan memahami diri, mengelola emosi, atau mampu mengendalikan emosi, motivasi, dan hasrat antar pribadi ini lebih menekankan pada aspek kognisi atau pemahaman. Sementara faktor emosi atau perasaan kurang diperhatikan. (Juntika, 2009: 240).

Berdasarkan hasil observasi awal pada bulan Oktober 2014 di MTs. Manba'ul Bayan Lingkung Kabupaten Lombok Tengah bahwa terdapat siswa yang memiliki kepribadian yang berbeda-beda, seperti kurang mampu mampu mengendalikan emosi, mengelola emosi, menghargai prasaan orang lain, mengendalikan emosi itu penting. Hal ini didasarkan atas kenyataan bahwa emosi mempunyai kemampuan untuk mengkomunikasikan diri kepada orang lain. Orang-orang yang individu jumpai di rumah atau di sekolah akan lebih cepat menanggapi emosi dari pada kata-kata. Kalau individu sampai di rumah dengan wajah murung, bahkan terkesan "cemberut" dan marah-mara emosi anggota keluarga yang lain akan bereaksi terhadap emosi kita, sehingga mereka tidak merasa enak atau merasa bersalah, dan sebagainya.

Sedangkan individu yang tidak mampu mengendalikan emosi, tak mampu memperjuangkan diri, sifat ingin membalas dendam, yaitu yang tidak mampu untuk berkonsentrasi dalam proses belajar mengajar karena adanya tekanan yang terjadi dari sikap teman-temannya sehingga tidak mampu mengendalikan emosinya sendiri.

Kepribadian adalah tingkah laku khas dan sifat seseorang yang membuatnya berbeda dengan orang lain. Kemudian, kepibadian dapat juga berarti integrasi karakteristik dari pola, minat, tingkah laku, 
potensi, pendirian, kemampuan dan strukturstruktur yang dimiliki orang lain. Dalam diri siswa ada yang mampu memahami dan mengendalikan perasaan serta gejolak yang muncul pada dirinya sendiri, bahkan adapula siswa yang sulit untuk memahami masalah yang ada pada perasaan emosi. Dalam masa perkembangan inilah seorang individu dituntut untuk memahami keinginan dan kebutuhan serta perasaan dorongan hati dan emosi secara cerdas, karena orang yang cerdas secara emosi bukan hanya memiliki emosi tetapi juga memahami perasaan tersebut selain itu individu yang cerdas secara emosi dapat melihat diri sendiri seperti orang lain melihatnya, mampu memahami orang lain seolah-olah apa yang dirasakan orang lain itu kita rasakan juga. Dengan kata lain siswa yang mampu memahami perasaan dan emosinya, biasanya akan cenderung lebih mampu memahami dirinya dan orang lain.

Berdasarkan uraian di atas, peneliti merasa tertarik untuk mengadakan penelitian tentang " hubungan antara kepribadian dengan kecerdasan emosi siswa pada kelas VII di MTs.Manba'ul bayan Lingkung Kabupaten Lombok Tengah Tahun Pelejaran 2015/2016 “.

\section{KAJIAN PUSTAKA \\ Kepribadian \\ Konsep Kepribadian}

Kepribadian (personality) sesungguhnya berasal dari kata latin: persona pada mulanya, kata persona ini menunjukan pada topeng yang biasa digunakan oleh pemain sandiwara di zaman Romawi dalam memainkan peranperannya atau teater. Pada saat itu, setiap pemain sandiwara memainkan perannya masing-masing sesuai dengan topeng yang dikenakannya.(Sobur, 2003: 299). Sedangkan ahli lain mengatakan bawha kepribadian adalah Syamsu dan Juntika, 2011: 3 mengemukakan bahwa secara populer, kepribadian dapat di artikan sebagai : (1) Ketrampilan atau kecakapan sosial (social skill), dan (2) Kesan yang paling menonjol, yang ditunjukan seseorang terhadap orang lain (seperti seseorang yang dikesankan sebagai orang yang agresif atau pendiam).

\section{Unsur-unsur kepribadian}

Unsur-Unsur kepribadian yaitu 1). Kepribadian itu merupakan organisasi yang dinamis. Dengan kata lain, ia tidak statis, tetapi senantiasa berubah setiap saat, 2) Organisai tersebut dapat dalam diri individu. Jadi, tidak meliputi hal-hal yang berada di luar diri individu, 3) Organisasi itu berdiri atas sistem psikis, yang menurut Allport meliputi, antara lain, sifat dan bakat, serta sistem fisik (anggota dan organ-organ tubuh) yang saling terkait dan Organisasi itu menentukan corak penyesuaian diri yang unik dari tiap individu terhadap lingkungannya. (Sobur, 2009: 300).

Faktor-faktor yang mempengaruhi perkembangan kepribadian

Perkembangan kepribadian individu di pengaruhi oleh berbagai faktor di antaranya yaitu 1). Faktor Genetika atau (pembawaan/biologis). Faktor biologis yaitu faktor yang berhubungan dengan keadaan jasmani, atau seringkali pula disebut faktor fisiologis. Dalam pembicaraan dalam temperamen, kita telah menyinggung konstitusi tubuh yang meliputi pencernaan, pernapasan, pereedaran darah, kelenjarkelenjar, urat saraf dan lain-lain, dan 2) Faktor sosial. Yang dimaksud dengan faktor sosial disini ialah masyarakat; yakni manusia-manusia lain disekitar individu yang mempengaruhi individu yang bersangkutan. Termasuk kedalam faktor sosial ini juga tradisi-tradisi, adat istiadat, peraturanperaturan, bahasa, dan sebangainya yang berlaku dalam masyrakat itu, dan 3). Faktor kebudayaan. Sebenarnya faktor kebudayaan termasuk pula kedalam faktor sosial seperti yang baru saja dibicarakan kita ketahui bahwa kebudayaan itu tumbuh dan berkembang didalam masyarakat. Kita dapat mengenal pula, bahwa kebudayaan tiap daerah/negara berlain-lainanan. (Purwanto, 2013:160) 
Ciri-ciri Individu yang memiliki kepribadian baik

Semua orang pasti menginginkan memiliki kepribadian yang baik. Banyak tingkah laku dan cara yang mereka lakukan untuk mengwujudkannya. Antara lain sebagai berikut: (1) Tidak ragu-ragu, tidak malu, tetapi berani, Harus dapat berdiri sendiri tanpa meminta bantuan dari orang lain, (2)Tidak merasa minder, tetapi mempunyai semangat kerja. Pujian yang tidak wajar dan teguran-teguran yang terlalu sering, bisa mematikan semangat kerja harga diri akan timbul dari prestasi kerja yang nyata, (3) Bersikap jujur terhadap diri sendiri. Berani melihat dengan sadar akan kekurangan diri sendiri. Bahkan, ia dapat memandang kekurangan-kekurangannya dengan rasa humor, (4) Mampu berdedikasi - penyerahan diri sendiri. Jangan di samakan dengan sikap "mengalah" yang tidak pada tempatnya, sehingga mudah di tindas sama orang lain dan tidak mempunyai kekuatan untuk mempertahankan diri dan (5) Senang kontak (berhubungan) dengan sesama. Kemampuan berkontak dinyatakan dalam tukar pikiran, membuka diri, diimbangi dengan kemampuan untuk menutup dan menjaga rahasia. (Sobur, 2009: 335).

\section{Ciri-ciri individu yang memiliki kepribadian yang kurang baik}

Ciri-ciri individu yang memiliki kepribadian yang kurang baik yaitu 1) Tidak mampu melakukan persahabatan, mengisolasikan diri, 2) Daya konsentrasi buyar; ketekunan dalam pekerjaan hancur, terlalu banyak melamun, 3) Penyangkalan terhadap nama, asal-usul, suku bangsa, masa lampau, dan sebagainya, 4) Tidak mampu memperjuangkan diri, kadang-kadang timbul keinginan mengakhiri hidup, bertalian dengan kebosanan hidup, dan sifat ingin membalas dendam; bereaksi terlalu radikal terhadap orang lain maupun dirinya sendiri; tidak mengakui dan tidak menerima masa lampaunya, lalu mau mengubah diri secara sangat radikal (identitas negatif). (Sobur, 2009: 335-336).

\section{Kecerdasan Emosi}

Konsep Kecerdasan Emosi

Juntika (2009: 240) mengatakan bahwa: "Kecerdasan emosi adalah kemampuan untuk memahami diri, mengelola emosi, memanfaatkan emosi secara produktif, empati dan membina hubungan". Sedangkan menurut Fatimah (2008: 115) mengatakan bahwa: Kecerdasan emosi adalah menuntut diri untuk belajar mengakui dan menghargai perasaan diri sendiri dan orang lain". Dari kedua pendapat di atas, maka peneliti dapat menyimpulkan bahwa kecerdasan emosi adalah kemampuan lebih yang dimiliki seseorang yang menuntut diri untuk bisa belajar mengakui dan menghargai perasaan diri sendiri dan orang lain, serta menanggapinya dengan tepat dan benar.

\section{Unsur-unsur yang membangun kecerdasan emosi}

Ada beberapa unsur yang dapat membangun kecerdasan emosi yaitu: “1). Memahami emosi-emosi sendiri, 2). Mampu mengelola emosi-emosi sendiri, 3). Memotivasi diri sendiri, 4). Memahami emosi orang lain, 5). Mampu membina hubungan sosial" (Fatimah, 2008:116-117). Untuk lebih jelasnya akan diuraikan sebagai berikut: 1) Memahami emosi diri. Kesadaran diri dalam mengenali perasaan sewaktu perasaan itu terjadi merupakan dasar kecerdasan emosional. Pada tahap ini diperlukan adanya pemantapan perasaan dari waktu ke waktu agar timbul pemahaman tentang diri, 2) Mampu mengelola emosiemosi sendiri Mengelola emosi berarti menangani perasaan agar terungkap dengan jelas, kecakapan yang sangat bergantug pada kesadaran diri. Emosi akan berhasil dikelola jika berhasil menghibur diri saat tertimpa kesedihan, 3) Memotivasi diri sendiri, 4) Mampu memotivasi diri ketika gejolak jiwa yang begitu dahsyat muncul dalam keseharian merupakan salah satu unsur yang menggambarkan seseorang memiliki tingkat kecerdasan emosi yang baik. Karena tidak banyak orang yang memiliki kemampuan dalam mengendalikan emosi pada saat yang 
bersamaan. Berdasarkan pendapat tersebut begitu pentingnya memotivasi diri sendiri dalam mendapatkan suatu kemandirian dan dorongan untuk melakuakan hal-hal yang lebih baik untuk kehidupan, 5) Memahami emosi orang lain. Empati untuk mengenal emosi orang lain dibangun berdasarkan kesadran diri. Seseorang terbuka pada emosi sendiri, ia akan terampil membaca perasaan orang lain begitu juga sebaliknya jika ia tidak mampu menyesuaikan diri dengan emosinya sendiri maka ia tidak akan mampu menghargai perasaan orang lain, 6) Mampu membina hubungan sosial dan 7) Membina hubungan sebagian besar merupakan keterampilan mengelola emosi orang lain atau dapat dikatakan mampu mengenali emosi orang lain. Dalam kehidupan bersosial di masyarakat pasti akan ditemukan berbagai bentuk emosi yang dimiliki oleh masingmasing individu, oleh karena itu orang yang mampu menjaga suasana hati atau emosi yang baik pasti akan mampu membina hubungan dengan baik pula.

\section{Faktor-faktor yang mempengaruh emosi}

Menurut Ekawati (2010 : 15) faktorfaktor yang mempengaruhi emosi yaitu : (1) Faktor Internal adalah faktor yang berasal dari dalam pribadi manusia itu sendiri yang dapat mempengaruhi emosi seseorang meliputi kondisi fisik dan psikologis. Faktor fisik antara lain: gangguan kesehatan atau kesehatan yang buruk, cacat tubuh, kencing manis, polio dan lain sebagainya. Gangguan kondisi fisik ini akan membawa anak kepada kepercayaan diri yang kurang, sehingga mempengaruhi emosi yang tidak setabil. Sedangkan kondisi psikologis ini sangat mempengaruhi emosi anak, misalnya seorang anak memiliki tingkat kemampuan di bawah normal atau rendah, sangat sulit beradaptasi dengan lingkungan, baik lingkungan keluarga, sekolah, dan masyarakat sehingga dapat menyebabkan emosi yang dimiliki menjadi tidak setabil. (2) Faktor eksternal meliputi: “a) lingkungan keluarga, Lingkungan keluarga atau keadaan keluarga juga dapat mempengaruhi keadaan emosi seseorang. Adapun keadaan keluarga yang dapat mempengaruhi emosi seseorang seperti: keadaan ekonomi, sikap orang tua, status keluarga, dan keinginan orang tua yang berlebihan dan tidak sesuai dengan kemampuan anak. b) lingkungan sekolah, Lingkungan sekolah dapat mempengaruhi kepribadian anak. Faktor-faktor yang di pandang berpengaruh itu di antaranya sebagai berikut. (1). Iklim emosional kelas; kelas yang iklim emosinya sehat (guru bersikap ramah,dan respek terhadap siswa dan begitu juga berlaku diantara sesama siswa) memberikan dampak yang positif bagi perkembangan psikis anak, seperti merasa nyaman, dan mau menaati praturan begitupun sebaliknya. (2). Sikapdan prilaku guru; sikap dan prilaku guru ini bercermin dalam hubungannya dengan siswa (relationship between teacher and student). Hubungan guru dengan siswa dipengaruhi oleh berbagai faktor. (3). Disiplin (tatatertip). (4). Prestasi belajar (5). Penerimaan teman sebaya. c) lingkungan masyarakat". Setiap kelompok masyarakat (bangsa, ras, atau suku) memiliki tradisi, adat, atau kebudayaan yang khas. Kebudayaan suatu masyarakat memberikan pengaruh terhadap setiap warganya, baik yang menyangkut cara berpikir (cara memandang sesuatu), cara bersikap, atau cara berprilaku. Pengaruh kebudayaan terhadap kepribadian ini dapat dilihat dari perbedaan antara masyarakat modern, yang budayanya maju dengan masyarakat primitif, yang budayanya masih sederhana. Perbedaan itu tampak dalam gaya hidupnya (life style) seperti dalam cara makan, berpakaian, memelihara kesehatan, berintraksi, pencaharian, dan cara berpikir (cara memandang sesuatu).(Syamsu \& Juntika, 2011: 30).

\section{METODE PENELITIAN}

Penelitian ini merupakan suatu penelitian korelasi atau penelitian hubungan adalah penelitian yang dilakukan untuk mengetahui tingkat hubungan antara dua variabel yaitu variabel $X$ (kepribadian) dan variabel Y (kecerdasan Emosi), tanpa melakukan perubahan atau manipulasi. 
Desain rancangan penelitiannya adalah sebagai berikut :

Gambar : 01 Rancangan Penelitian Korelasi Antara variabel X dan Variabel Y

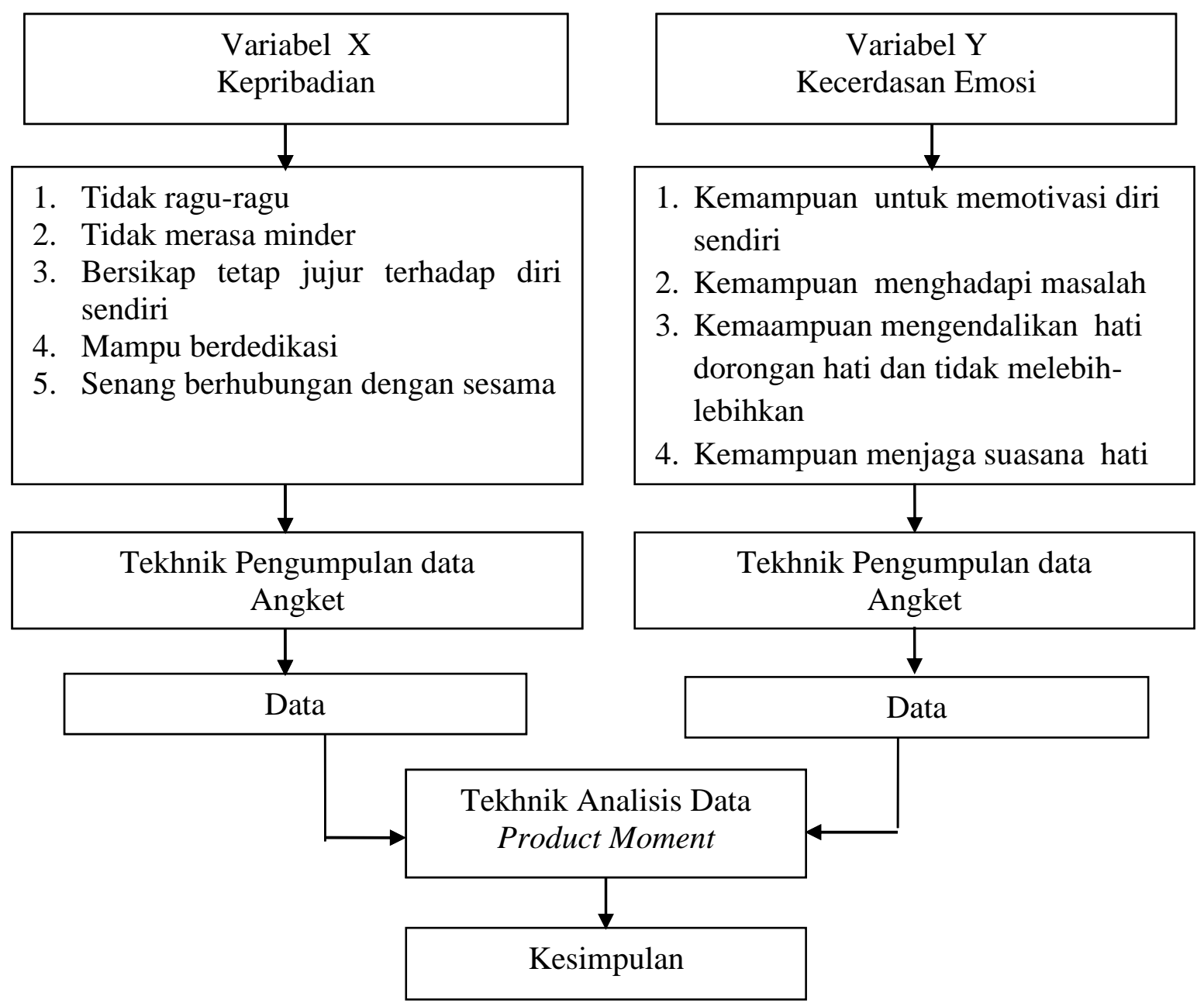

Populasi dari penelitian ini adalah seluruh siswa kelas VII di MTs. Manba'ul Bayan Lingkung Kabupaten Lombok Tengah Tahun Pelajaran 2015/2016 yang berjumlah 19 siswa, sedangkan sampel yang akan digunakan adalah sesuai dengan teknik penentuan sampel apabila populasi lebih dari 100 maka populasi menggunakan proportinonal ramdom sampling dan jika jumlah populasi kurang dari 100 orang, maka lebih baik diambil semuanya, dan jika lebih dari 100 maka diambil $10 \%$ - $15 \%$ atau $20 \%$ - $25 \%$ atau tergantung dari kebutuhan dan kemampuan peneliti. (Suharsimi, 2009 : 134). Karena populasinya kurang dari 100 yakni 19 orang siswa, maka diambil semuanya, jadi merupakan penelitian populasi. Metode pengumpulan data adalah angket sebagai metode pokok, sedangkan metode dokumentasi sebagai metode pelengkap.

Instrumen yang digunakan adalah dalam bentuk angket tertutup dan secara langsung diberikan kepada siswa, dan langsung dijawab oleh responden (subyek) dan responden (subyek) tinggal memilih jawaban yang sesuai dengan keadaan dirinya. Dalam penelitian ini, instrumen yang digunakan adalah berupa angket. Adapun angket ini merupakan alat pengumpulan data yang dilakukan dengan cara memberi pertanyaan secara tertulis kepada responden untuk dijawab secara tertulis pula. Dalam penelitian ini, angket disusun dalam bentuk sejumlah pertanyaan untuk dijawab oleh responden (siswa) kaitannya dengan hubungan 
kepribadian dengan kecerdasan emosi, dimana dalam instrumen ini terdiri dari dua variabel yaitu variabel $\mathrm{x}$ adalah kepribadian dan variabel $Y$ adalah kecerdasan emosi.

Adapun indikator angket kepribadian adalah (1) Tidak ragu-ragu, (2) Tidak merasa minder, (3) Bersikap tetap jujur terhadap diri sendiri, (4) Mampu berdedikasi, dan (5) Senang berhubungan dengan sesama. Sedangkan indikator angket kecerdasan emosi adalah (1) kemampuan untuk memotivasi diri sendiri, (2) kemampuan menghadapi masalah, (3) Kemampuan mengendalikan dorongan hati dan tidak melebih- lebihkan dan (4) Kemampuan menjaga suasana hati.

Adapun indikator penilaian angket yang disebarkan, dilakukan dengan skala tiga yang terdiri dari 3 (tiga) alternatif jawaban (option) yaitu: Apabila responden menjawab "a" (ya) skor nilai $=3$, Apabila responden menjawab "b" (kadang-kadang) skor nilai = 2 dan apabila responden menjawab "c" (tidak) skor nilai $=1$. Data hasil angket ini kemudian diolah dan dianalisis secara intensif dan sistematis atau teratur sesuai dengan keadaan yang sebenarnya. Metode analisis data yang digunakan dalam penelitian ini adalah menggunakan rumus korelasi product moment.

\section{HASIL PENELITIAN}

Setelah dilakukan penelitian dan mengumpulkan data hasil penelitian tentang angket hubungan antara kepribadian dengan kecerdasan emosi siswa kelas VII di MTs. Manba'ul Bayan Lingkung Kabupaten Lombok Tengah Tahun Pelajaran 2015/2016, kemudian dilakukan analisis untuk mendapatkan hasil dan gambaran dari indikator penelitain. Berdasarkan hasil penyebaran angket angket hubungan antara kepribadian dengan kecerdasan emosi siswa kelas VII di MTs. Manba'ul Bayan Lingkung Kabupaten Lombok Tengah, hubungan antara keharmonisan keluarga dengan sikap sosial siswa di SMP Negeri 3 Praya Barat Daya, dari hasil nilai data kepribadian sebesar sebesar 902 dan hasil data angket kecerdasan emosi yaitu sebesar 806 .
Adapun langkah-langkah yang ditempuh dalam analisis data adalah sebagai berikut : 1) Merumuskan hipotesis nihil (Ho). Sehubungan dengan analisis data yang menggunakan analsis statistik, maka hipotesis alternatif (Ha) yang diajukan berbunyi : "Ada hubungan kepribadian dan kecerdasan emosi di kelas VII MTs. Manbu'ul Bayan Lingkug Kabupaten Lombok Tengah Tahun Pelajaran 2015/2016", diperlukan perubahan terlebih dahulu menjadi hipotesis nihil (Ho) yang berbunyi : "Tidak ada hubungan kepribadian dan kecerdasan emosi di kelas VII MTs.Manbu'ul Bayan Lingkug Kabupaten Lombok Tengah Tahun Pelajaran 2015/2016.

2) Membuat tabel kerja. Tabel kerja untuk pengolahan data yang telah dikumpulkn dengan metode angket tentang kepribadian dan kecerdasan emosi di kelas VII MTs.Manbu'ul Bayan Lingkug Kabupaten Lombok Tengah Tahun Pelajaran 2015/2016. 3) Memasukkan data ke Dalam Rumus. Berdasarkan data pada tabel diatas, maka data-data tersebut dimasukkan ke dalam rumus sebagai berikut :

$\mathrm{rxy}=$

$$
\begin{aligned}
& \frac{N \cdot \sum X Y-\left(\sum X\right)\left(\sum Y\right)}{\sqrt{\left\{N \cdot \sum X^{2}-\left(\sum X\right)^{2}\right\}\left\{N \cdot \sum Y^{2}-\left(\sum Y\right)^{2}\right\}}}= \\
& \frac{19.38804-(806)(902)}{\sqrt{\left\{19.35060-(806)^{2}\right\}\left\{19.43822-(902)^{2}\right\}}}= \\
& \frac{737276-727012}{\sqrt{\{66140-64636\}\{832618-813604\}}} \\
& =\frac{10264}{\sqrt{16504-19014}}=\frac{10264}{\sqrt{313807056}}= \\
& \frac{10264}{17714 ., 6}=0,579=0,58
\end{aligned}
$$

4) Menguji Koefisien Korelasi Product Moment. Dari hasil perhitungan rxy yang diperoleh dalam penelitian ini adalah 0,579, sedangkan nilai rxy dalam tabel dengan taraf signifikan 5\% dan $\mathrm{N}=19$ adalah 0,456 atau $(0,58>0,456)$. Kenyataan ini menunjukkan bahwa nilai rxy yang diperoleh dalam penelitian ini lebih besar dari pada nilai rxy dalam tabel. 5) Menarik Kesimpulan. Berdasarkan hasil perhitungan nilai rxy yang 
diperoleh dalam penelitian ini adalah 0,579, sedangkan nilai rxy dalam tabel dengan taraf signifikansi $5 \%$ dan $\mathrm{N}=19$ adalah 0,456 , atau $(0,58>0,456)$, kenyataan ini menunjukan bahwa nilai rxy yang di peroleh dalam penelitian ini adalah lebih besar dari pada nilai rxy tabel. Maka di kemukakan bahwa hipotesis nol (Ho) di tolak dan hipotesis alternatif (Ha) di terima. Jadi kesimpulan analisis dalam penelitian ini adalah sebagai berikut: Ada hubungan antara kepribadian dengan kecerdasan emosi pada siswa kelas VII MTs. Manba'ul Bayan Lingkung Kabupaten Lombok Tengah Tahun Pelajaran 2015/2016.

Tabel 01: Tabel Kerja Tentang Hubungan antara Kepribadian dengan Kecerdasan Emosi pada siswa kelas VII MTs. Manba'ul Bayan Lingkung Kabupaten Lomnbok Tengah Tahun pelajaran 2105/2016

\begin{tabular}{|c|l|l|l|l|l|l|}
\hline No & Subjek & \multicolumn{1}{|c|}{$\mathbf{X}$} & $\mathbf{Y}$ & $\mathbf{X}^{\mathbf{2}}$ & $\mathbf{Y}^{\mathbf{2}}$ & $\mathbf{X Y}$ \\
\hline$(1)$ & $(2)$ & $(3)$ & $(4)$ & $(5)$ & $(6)$ & $(7)$ \\
\hline 1 & BS & 43 & 35 & 1849 & 1225 & 1505 \\
\hline 2 & BQSA & 44 & 44 & 1936 & 1936 & 1936 \\
\hline 3 & DS & 54 & 47 & 2936 & 2209 & 2538 \\
\hline 4 & HH & 45 & 37 & 2025 & 1369 & 1655 \\
\hline 5 & HS & 49 & 36 & 2401 & 1296 & 1746 \\
\hline 6 & LH & 45 & 49 & 2025 & 2401 & 2205 \\
\hline 7 & LRP & 52 & 44 & 2704 & 1936 & 2288 \\
\hline 8 & MI & 65 & 64 & 4225 & 4096 & 4160 \\
\hline 9 & MP & 51 & 47 & 2601 & 2209 & 2397 \\
\hline 10 & MA & 42 & 34 & 1764 & 1156 & 1428 \\
\hline 11 & MAS & 39 & 36 & 1521 & 1296 & 1404 \\
\hline 12 & MR & 51 & 43 & 2601 & 1849 & 2193 \\
\hline 13 & MT & 53 & 38 & 2809 & 1521 & 2067 \\
\hline 14 & PD & 53 & 37 & 2809 & 1369 & 1961 \\
\hline 15 & PM & 45 & 47 & 2025 & 2209 & 2115 \\
\hline 16 & SF & 36 & 42 & 1225 & 1764 & 1470 \\
\hline 17 & SN & 36 & 39 & 1225 & 1521 & 1365 \\
\hline 18 & WR & 56 & 43 & 3136 & 1849 & 2408 \\
\hline 19 & WS & 45 & 43 & 2025 & 1849 & 1935 \\
\hline JUMLAH & $\mathbf{9 0 2}$ & $\mathbf{8 0 6}$ & $\mathbf{4 3 8 2 2}$ & $\mathbf{3 5 0 6 0}$ & $\mathbf{3 8 8 0 4}$ \\
N=19 & & & & & & \\
\hline
\end{tabular}

Berdasarkan tabel kerja tentang judul Hubungan Antara Kepribadian dengan Kecerdasan Emosi pada siswa kelas VII MTs. Manba'ul Bayan Lingkung Kabupaten Lombok Tengah Tahun Pelajaran 2015/2016 merupakan $\mathrm{X}$ hasil dari variabel kepribadian yang berjumlah 902 dan $\mathrm{Y}$ hasil dari Kecerdasan Emosi 806 dan $\mathrm{X}^{2}$ berjumlah 43822, $\quad \mathrm{Y}^{2}$ berjumlah 35060 dan $\mathrm{XY}$ berjumlah 38804 .

\section{PEMBAHASAN}

Berdasarkan hasil analisis yang diperoleh dalam penelitian ini adalah niai rxy 0,579 , sedangkan nilai rxy dalam tabel dengan taraf signifikansi $5 \%$ dan $\mathrm{N}=19$ adalah $0, \quad 0456$, atau $(0,579>0,456)$, kenyataan ini menunjukan bahwa nilai rxy yang di peroleh dalam penelitian ini adalah lebih besar dari pada nilai rxy tabel. Maka di kemukakan bahwa hipotesis nol (Ho) di tolak dan hipotesis alternatif (Ha) di terima. Jadi kesimpulan analisis dalam penelitian ini adalah sebagai berikut: Ada hubungan antara 
kepribadian dengan kecerdasan emosi pada siswa kelas VII MTs. Manba'ul Bayan Lingkung Kabupaten Lombok Tengah Tahun Pelajaran 2015/2016. Ada hubungan antara kepribadian dengan kecerdasan siswa pada kelas VII di MTs.Manba'ul bayan Lingkung Kabupaten Lombok Tengah Tahun Pelejaran 2015/206.

Kepribadian adalah (1) Ketrampilan atau kecakapan sosial (social skill), dan (2) Kesan yang paling menonjol, yang ditunjukan seseorang terhadap orang lain (seperti seseorang yang dikesankan sebagai orang yang agresif atau pendiam). Sedangkan Kecerdasan emosi adalah kemampuan untuk memahami diri, mengelola emosi, memanfaatkan emosi secara produktif, empati dan membina hubungan.

Untuk mampu mengembangkan kepribadian dan kecerdasan emosi, perlu menerima pendapat orang lain, baik di dalam keluarga maupun di lingkungan masyarakat, memerlukan kepribadian yang baik dalam msyarakat. Dalam membentuk kepribadian yang baik dibutuhkan dan diperlukan peran orang tua maupun keluarga, sehingga anak mampu menyesuaiakan diri dengan lingkungan sosial agar memiliki nilai positif yaitu dibutuhkan emosional dalam diri individu tersebut maka individu itu sendiri dengan memahami seutuhnya tentang diri dan lingkungan dan mampu menempatkan dirinya sesuai dengan aturan yang berlaku.

Hasil penelitian secara keseluruhan diketahui bahwa ada hubungan antara kepribadian dengan kecerdasan emosi pada siswa adalah Signifikan, hal ini berdasarkan hasil perhitungan nilai rxy yang diperoleh dalam penelitian ini adalah 0,579 , sedangkan nilai rxy dalam tabel dengan taraf signifikansi $5 \%$ dan $\mathrm{N}=19$ adalah 0,456 , atau $(0,579>0,456)$, kenyataan ini menunjukkan bahwa nilai rxy yang diperoleh dalam penelitian ini adalah lebih besar dari pada nilai rxy tabel. Maka dapat dikemukakan bahwa hipotesis nol (Ho) ditolak dan hipotesis alternatif (Ha) diterima. Jadi kesimpulan analisis dalam penelitian ini adalah sebagai berikut: Ada hubungan antara kepribadian dengan kecerdasan emosi pada siswa kelas VII MTs. Manba'ul Bayan Lingkung Kabupaten Lombok Tengah Tahun pelajaran 2015/2016.

\section{KESIMPULAN}

Berdasarkan hasil perhitungan nilai rxy yang diperoleh dalam penelitian ini adalah 0,579, sedangkan nilai rxy dalam tabel angket batas penolakan hipotesis nihil dengan taraf signifikansi $5 \%$ dan $\mathrm{N}=19$ adalah 0,579 , atau $(0,58>0,456)$, kenyataan ini menunjukkan bahwa nilai rxy yang diperoleh dalam penelitian ini adalah lebih besar dari pada nilai rxy tabel, maka dapat dikemukakan bahwa hipotesis nol (H0) ditolak dan hipotesis alternatif (Ha) diterima. Jadi kesimpulan analisis dalam penelitian ini adalah sebagai berikut: Ada hubungan antara kepribadian dengan kecerdasan emosi pada siswa kelas VII MTs. Manba'ul Bayan Lingkung Kabupaten Lombok Tengah Tahun pelajaran 2015/2016. Sehingga Ada hubungan antara kepribadian dengan kecerdasan emosi pada siswa kelas VII MTs. Manba'ul Bayan Lingkung Lombok Tengah Tahun pelajaran 2015/2016 yang "Signifikan".

\section{DAFTAR PUSTAKA}

Arikunto, Suharsimi. (2009). Prosedur Penelitian. Jakarta : Rineka Cipta

Cervone, Daniel., Pervin, Lawrence A. (2011). Kepribadian: Teori dan Penelitian. Edisi 10, Buku 1. Jakarta: Salemba Humanika.

Eni Ekawati. (2011). Hubungan Antara Pemahaman Diri Dengan Pengendalian Emosi Siswa SMP Negeri 1 Kayangan Lombok Utara Tahu Pelajaran 2010/2011(skripsi) IKIP Mataram.

Fatimah, Enung. (2008). Psikologi Perkembangan. Bandung : CV. Pustaka Setia

Nurihsan. Juntika.(2009).Landasan Bimbinga $\mathrm{n}$ dan Konseling: Bandung PT.Remaj a Rosdakarya

Purwanto Ngalim M. (2013). Psikologi pendidikan Bandung: PT Remaja Rosdakarya. 
Sobur, Alex.(2009). Psikologi Umum.

Bandung : CV. Pustaka Setia.

Yusuf Syamsu (2011). Psikologi perkembangan anak dan remaja.

Bandung: PT Remaja Rosdakary 